\title{
System of Risk Analysis and Management in the Context of Ensuring the Customs Security of Ukraine
}

The article explores theoretical approaches and normative legal bases of functioning of the system of risk analysis and management in the context of ensuring the customs security of Ukraine.

The basic approaches to the categories "risk", "customs risk", "customs security" are defined. Based on the analysis of the definition of the concept of "customs risk" in international law and the scientific literature, it can be concluded that it should be interpreted as the probability of non-compliance or violation of the rules of domestic customs legislation and the procedure of conducting foreign trade operations by economic entities, which leads to the occurrence of customs damage .

Customs regulations aimed at ensuring streamlining of the practical application of the risk analysis and management system are investigated. It also defines the expanded conceptual and categorical apparatus of customs risk management, the corresponding accompanying classifiers of forms of customs control, violations, areas of risk, etc., specifies the features of actions of officials of customs authorities in the application of automatic risk analysis and management system, as well as the procedure for development, formalization, testing, implementing and monitoring the effectiveness of risk profiles. It is established that the analysis process is carried out in two main stages: 1) risk assessment for each risk profile; 2) determination of the list of forms of control as a whole for customs declarations.

Establishing an effective risk management system involves the introduction of a range of measures, including: mandatory prior notification by carriers; expanding the use of electronic declaration; construction of an institute of authorized economic operator; shifting the emphasis of fiscal risk control, including customs value, to the stage after completion of customs clearance; introduction of advanced information and technical solutions in the field of customs control, including automated production of goods. customs risk, customs risk management, customs security, risk management

\section{Передумови формування інноваційно-інтегрованих структур в умовах посилення освітньої міграції: регіональний аспект}

У статті досліджено передумови формування інноваційно-інтегрованих структур в умовах посилення освітньої міграції. Здійснено оцінку результатів зовнішнього незалежного оцінювання у Кіровоградській області. Проведено компаративний аналіз результативності вступної кампанії ЗВО у територіальному розрізі. Здійснено якісний аналіз аплікаційних заяв абітурієнтів регіональних 3 ВО та ТОП-10 університетів 3 найвищим рейтинговим балом ЗНО. Виявлено, що найбільш дієвим інструментом усунення проявів освітньої міграції є поглиблення співпраці органів місцевої влади, бізнесу та закладів вищої освіти, тобто створення передумов для формування інноваційно-інтегрованих структур.

заклад вищої освіти, вища освіта, зовнішне незалежне оцінювання, інноваційно-інтегровані структури

И.А. Царенко, канд. екон. наук

Центральноукраинский нацииональный технический университет, г. Кропивницкий, Украина

Предпосылки формирования инновационно-интегрированных структур в условиях усиления образовательной миграции: региональный аспект

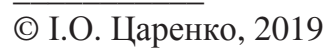


В статье исследованы предпосылки формирования инновационно-интегрированных структур в условиях усиления образовательной миграции. Осуществлена оценка результатов внешнего независимого оценивания в Кировоградской области. Проведен компаративный анализ результативности вступительной кампании вузами в территориальном разрезе. Осуществлен качественный анализ аппликационных заявлений абитуриентов региональных ЗВО и ТОП-10 университетов с самым высоким рейтинговым баллом ВНО. Выявлено, что наиболее действенным инструментом устранения проявлений образовательной миграции является углубление сотрудничества органов местной власти, бизнеса и ВУЗов , то есть создание предпосылок для формирования инновационно-интегрированных структур.

ВУЗ, высшее образование, внешнее независимое оценивание, инновационно-интегрированные структуры

Постановка проблеми. В умовах формування економіки, заснованої на знаннях та компетенції, рушійною силою розвитку будь-якої території, як регіону, так i країни в цілому, є людський капітал, адже саме він $є$ ключовим пріоритетом стратегічного розвитку в сучасних умовах трансформаційних перетворень. Людський капітал, як ніякий інший ресурс, сприяє зростанню продуктивності праці, завдяки чому впливає на зростання доходів як самого власника, так і національного доходу в цілому.

Як показує зарубіжний досвід, на рівень розвитку людського капіталу впливає сфера вищої освіти, адже саме освітні інституції продукують нові знання, інноваційноорієнтовані, з огляду на вимоги сучасного середовища, як у вигляді безпосередньо нових знань, розробок, так і випускників, які працевлаштовуючись, забезпечують вищу продуктивність праці, аніж працівники без вищої освіти. Такий аспект набуває все більшою актуальності з точки зору децентралізації влади, необхідності розвитку територій, що можливе виключно шляхом ефективної політики посилення кластеризації регіонів, формування в межах таких територій інноваційно-інтегрованих структур.

Аналіз останніх досліджень і публікацій. Дослідження різноманітних теоретичних і прикладних аспектів розвитку вищої освіти України, ії значення у напрямку посилення конкурентоспроможності економіки країни в цілому відображено в працях таких вчених як: М. П. Вербового, О. І. Гонта, І. С. Каленюк [4], О. О. Кукліна [5], О. М. Левченка [1], Н. В. Ушенко [9], Н. І. Холявко [4; 10] та ін. Зокрема, О. М. Левченко вивчав особливості інноваційного виміру розвитку вищої освіти України: сучасні реалії та іiї перспективи [1]. В продовження даного напрямку наукового пошуку, варто відзначити, наукову працю Н. І. Холявко щодо сектору вищої освіти в системі інноваційного розвитку національної економіки [10].

Крім того, варто відзначити вагомий внесок I. Ф. Прокопенко та О. В. Мельникової у проблематику дослідження ролі вищої освіти як фактору економічного зростання держави [7].

Проте, відсутність досліджень стосовно освітньої міграції з точки зору іï впливу не лише на стан розвитку вищої освіти України, а й передумови формування інноваційно-інтегрованих структур викликає ряд суперечностей в недостатній оцінці іiі значення в умовах трансформаційних перетворень та посилення необхідності радикальних заходів щодо зниження рівня освітньої міграції, в першу чергу, випускників шкіл, тому виникає необхідність компаративного аналізу результатів вступних компаній впродовж останніх років для здійснення оцінювання передумов формування інноваційно-інтегрованих структур в Україні з точки зору освітньої компоненти їх формування.

Постановка завдання. Метою даного дослідження $є$ здійснення аналізу передумов формування інноваційно-інтегрованих структур у спектрі дослідження явища освітньої міграції, в тому числі у регіональному аспекті, особливо у призмі 
наявного дефіциту висококваліфікованих кадрів в умовах сучасних тенденцій децентралізації.

Виклад основного матеріалу. Сьогодні, в умовах, визначеної державою, стратегії децентралізації економіки України, постає досить гостро питання стратегії розвитку регіонів, що можливе лише шляхом забезпечення таких територій висококваліфікованими кадрами, підготовка яких здійснюється закладами вищої освіти (3ВО). Проте, сьогодні спостерігається дисбаланс цього аспекту: регіональні 3ВО, які є основним постачальником робочої сили на регіональні ринки праці, користуються попитом серед учнів регіональних шкіл з більш низькими результатами зовнішнього незалежного оцінювання (ЗНО). Таким чином, уже на вході, потенціал таких випускників $\epsilon$ нижчим аніж у випускників інших «столичних» ЗВО, куди направляються абітурієнти «200»-ники. Вважаємо, що ступінь засвоєння знань студентами в університеті, базово, залежить від ступеня знань та навичок, засвоєних студентами в школах, що й виступає гіпотезою даного дослідження.

Підтвердженням даного взаємозв' язку можуть слугувати висновки попереднього дослідження, в ході якого було встановлено, що області, випускники шкіл яких склали зовнішнє незалежне оцінювання з найвищими результатами, є областями з найвищими якісними позиціями у підготовці майбутніх фахівців та є найбільш популярними серед абітурієнтів, як осередок накопичення нових знань [11, с. 79], та, окрім того, середовищем створення науково-технічних парків за участі університетів.

Таким чином, аналізуючи рис. 1 та наявну статистику, спостерігаємо наступне: у 2016 році у Кіровоградській області успішно склали ЗНО з української мови (180-200 балів) 656 осіб, у 2019 році - 632 особи, з математики - 96 осіб у 2016 році та 165 осіб у 2019 році, з історії України - 200 осіб у 2016 році та 161 особа у 2019 році, з фізики 13 осіб у 2016 році та 14 осіб у 2019 році, з хімії - 40 осіб у 2016 році та 27 осіб у 2019 році, з біології - 110 осіб у 2016 році та 80 осіб у 2019 році, з географії - 47 осіб у 2016 році та 99 осіб у 2019 році, з англійської мови - 100 осіб у 2016 році та 178 осіб у 2019 році та 3 німецької мови - 1 особа у 2016 році та 0 осіб у 2019 році.

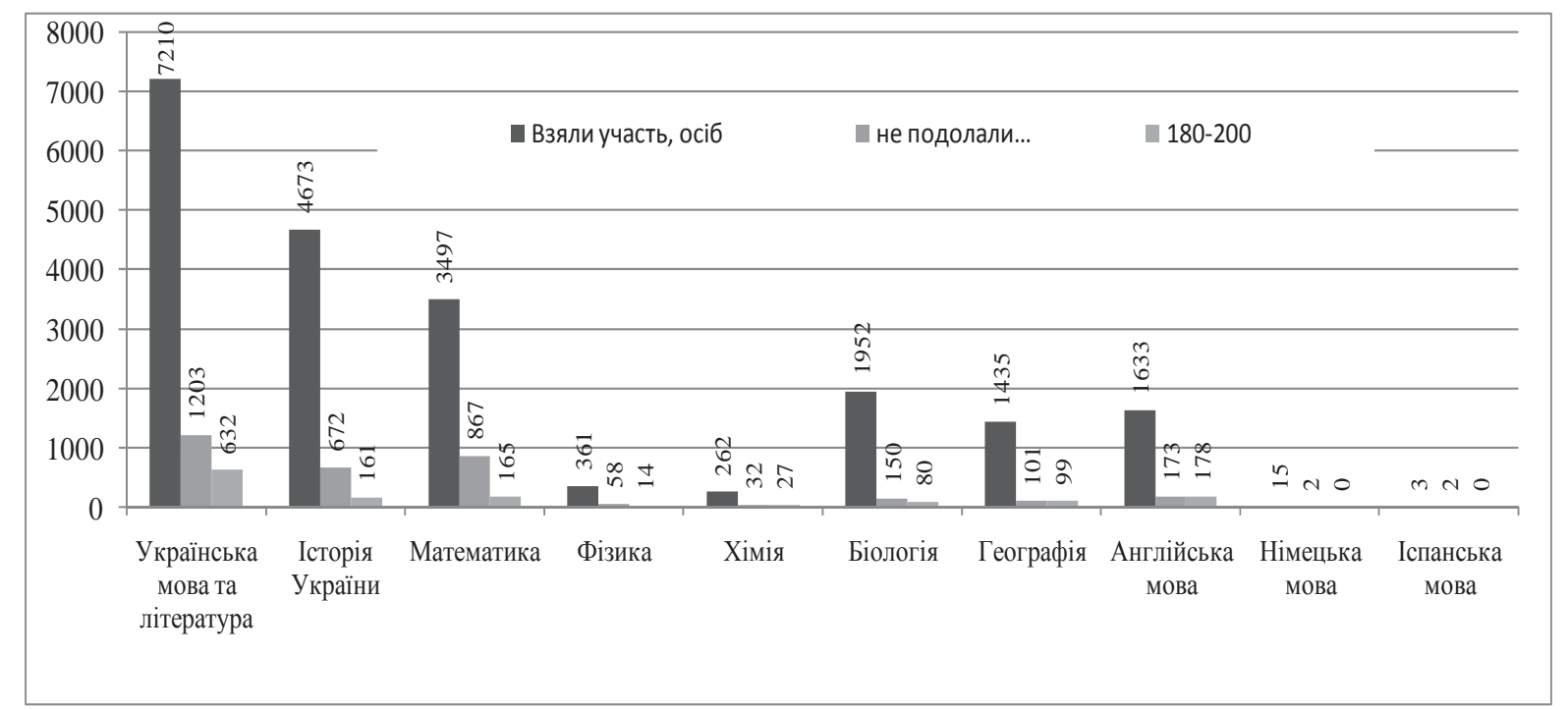

Рисунок 1 - Аналіз результатів ЗНО у 2019 році по Кіровоградській області, у розрізі предметних дисциплін, бали

Джерело: побудовано автором на основі [8]. 
Виходячи 3 результатів попередніх досліджень [6, с. 47], нами було проаналізовано аплікаційні заяви вступників та зарахованих до ЗВО Кіровоградської області у розрізі середнього балу за сертифікатами ЗНО. Звідси спостерігаємо, що лише 36 заяв із результатом 190-200 балів та 153 заяви із 180-190 балів було подано до регіональних 3ВО, що становить лише 14,9 \% від загальної чисельності осіб з такими результатами. Але, як наслідок, до регіональних ЗВО не вступив жоден студент 3 такими результатами, що свідчить про те, що університети області не були пріоритетними серед абітурієнтів. А найбільша чисельність абітурієнтів (166 осіб), які стали студентами першого курсу регіональних 3ВО, мала середній бал сертифікатів зовнішнього незалежного оцінювання - 130-140 балів.

Таким чином, до регіональних ЗВО вступають випускники шкіл області з досить низькими результатами ЗНО. В результаті, професорсько-викладацький склад університетів працює зі студентами, потенціал яких є значно меншим, аніж в університетах, де вступають абітурієнти з високими балами ЗНО, що вимагає більше сил та часу не лише на засвоєння матеріалу, а й на здатність продукувати щось нове та креативне такими студентами.

Таким чином, описана вище ситуація впливає на результат освітнього процесу, зокрема, конкурентоспроможність випускників 3ВО.

Як підтвердження нашої гіпотези, наводимо результати дослідження вітчизняних вчених, відповідно до проведеної ними кластеризації регіонів України за результатами оцінки конкурентоспроможності випускників ЗВО: найвищими оцінками конкурентоспроможності відрізняються випускники ЗВО м. Києва; випереджають інші регіони також Львівська, Одеська, Харківська обл. Для регіонів-лідерів характерні високий рівень розвитку ринку праці й ринку освітніх послуг, значні фінансові можливості для інноваційної діяльності, наявність сформованих наукових шкіл. Для регіонів-аутсайдерів (серед них Кіровоградська область) притаманні найнижчі показники якості вищої освіти і підготовки фахівців, найвищий рівень безробіття, найнижчий рівень оплати праці, високий ступінь зносу основних засобів, обмежені можливості інвестування інноваційної діяльності, низька якість робочих місць через невисоку заробітну плату [1, с. 151].

Таким чином, на підставі результатів наведеного вище аналізу, стверджуємо, що в Україні вибудовується диференціація регіонів за контингентом студентів, зокрема як за якісними, так і кількісними складовими. В результаті, потенціал трудових ресурсів в регіонах є нерівнозначним. Більше того, відсутність заохочень для вступу в регіональні ЗВО абітурієнтів 3 вищими результатами ЗНО призводить до зниження потенціалу депресивних регіонів, для яких саме людський ресурс, зокрема саме інтелектуальна еліта, є одним із шляхів виведення регіону із кризового стану. Дана ситуація стає більш критичною та свідчить про проблемний аспект у зв' язку з політикою децентралізації.

Далі, вважаємо за потрібне, проаналізувати, у розрізі всіх регіонів України ступінь зацікавленості регіоном, як місцем навчання та, потенційно, місцем майбутнього працевлаштування, кількість заяв абітурієнтів до ЗВО у 2019 році (рис. 2) та, відповідно, відношення заяв абітурієнтів у ЗВО певної області до загальної кількості заяв у 2019 році (рис. 3), що дає змогу виявити найбільш популярні регіони в Україні. 


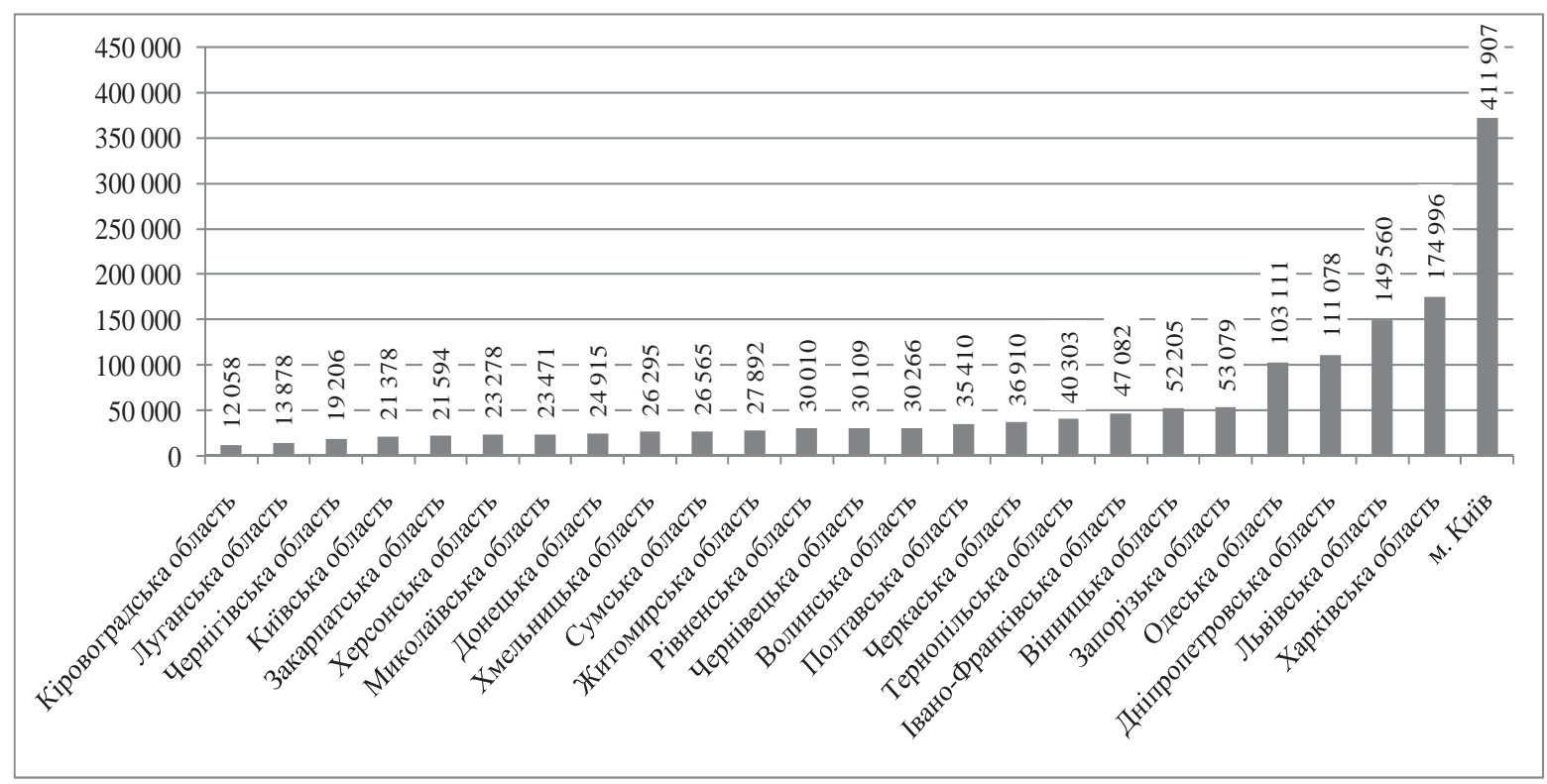

Рисунок 2 - Аналіз заяв абітурієнтів до закладів вищої освіти України за регіонами у 2019 році, од. Джерело: побудовано автором на основі [2; 3].

Аналізуючи рис. 2, спостерігаємо, що найбільш популярними регіонами серед абітурієнтів у 2016 та 2019 році були такі: м. Київ - 450846 од. заяв у 2016 році та 411907 од. у 2019 році, Харківська область - 208857 од. заяв у 2016 році та 174996 од. у 2019 році, Львівська область - 174027 од. заяв у 2016 році та 149560 од. у 2019 році, Дніпропетровська область - 138205 од. заяв у 2016 році та 111078 од. у 2019 році та Одеська область - 124820 од. заяв у 2016 році та 103111 од. Найнижча кількість заяв (13 850 од. у 2016 році та 12058 од. у 2019 році) - Кіровоградська область: Не дивлячись на той факт, що дані є абсолютними, вони повністю відображають попередні висновки щодо диференціації регіонів. Проте, вважаємо, що відносний показник, який відображає відношення загальної кількості заяв у ЗВО певного регіону до загальної кількості заяв по Україні є більш важливим, адже відображає більш компаративний характер (рис. 3).

Як можемо спостерігати 3 рис. 3, чверть заяв абітурієнтів із усієї України припадає на м. Київ (26,6 \% у 2019, що зросло у порівнянні з 24,6 \% у 2016 році), Харківська область прийняла $11,4 \%$ від усієї кількості у 2016 році та 11,3 \% у 2019 році відповідно, Львівська область - 9,7 \% у 2019, що зросло у порівнянні з 9,5\% у 2016 році, Дніпропетровська область - 7,2 \% у 2019, що знизилось у порівнянні з 7,6 \% у 2016 році, Одеська область - 6,7 \% у 2019, що знизилось у порівнянні з 6,8 \% у 2016 році, Запорізька й Вінницька області - по 3,4 \% у 2019, що знизилось у порівнянні 3,6 $\%$ у 2016 році. Найменша вага заяв абітурієнтів припадає на Кіровоградську область 0,8\% від загальної кількості заяв.

Проте, звичайно, порівнювати, наприклад, Кіровоградський регіон із м. Києвом, Харківською, Львівською, Дніпропетровською чи Одеською областями є недоречним, адже мережа ЗВО в цих областях є ширшою, тому, вважаємо за доречне, порівняти обсяг ліцензійного замовлення ЗВО регіону із загальною кількістю заяв по регіону у вигляді табл. 1. 


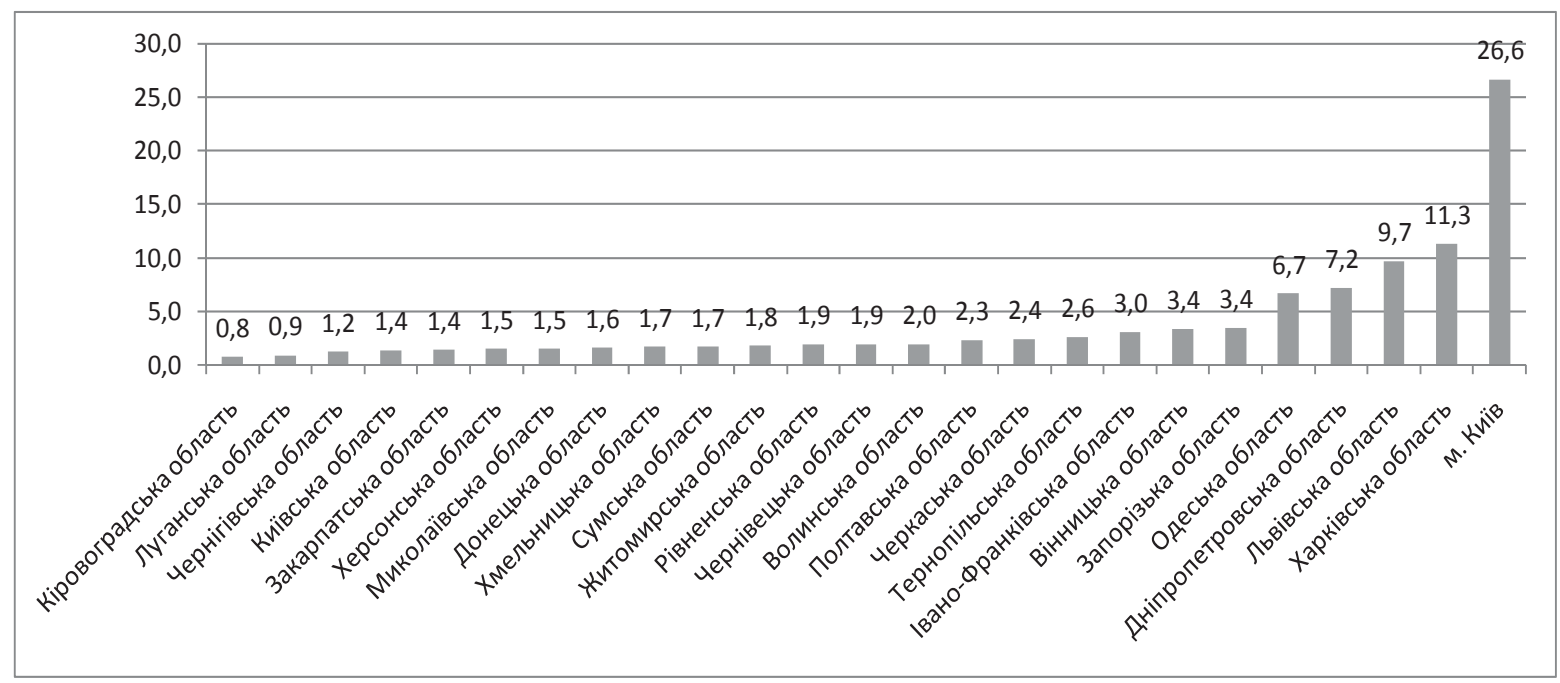

Рисунок 3 - Відношення кількості заяв до закладу вищої освіти певного регіону до загальної кількості заяв по Україні у 2019 році, \%

Джерело: побудовано автором на основі [2; 3].

3 табл. 1 отримуємо, що загалом по Україні спостерігається незаповненість контингенту ЗВО студентами.

Таблиця 1 - Порівняльна характеристика ліцензійного замовлення 3ВО із загальною кількістю заяв за регіонами України у 2019 році, од.

\begin{tabular}{|c|c|c|c|c|c|}
\hline \multirow[t]{2}{*}{ Назва області } & \multirow{2}{*}{$\begin{array}{c}\text { Ліцензійний } \\
\text { обсяг, од. }\end{array}$} & \multirow{2}{*}{$\begin{array}{l}\text { Кількість } \\
\text { заяв, од. }\end{array}$} & \multirow{2}{*}{$\begin{array}{c}\text { Кількість } \\
\text { оригіналів, } \\
\text { од. }\end{array}$} & \multicolumn{2}{|c|}{$\begin{array}{c}\text { Заповненість ліцензійного } \\
\text { обсягу ЗВО загалом, \% }\end{array}$} \\
\hline & & & & заявами & оригіналами \\
\hline м. Київ & 314936 & 411907 & 78870 & 131 & 25 \\
\hline Вінницька область & 54343 & 52205 & 14831 & 96 & 27 \\
\hline Волинська область & 29999 & 30266 & 7189 & 101 & 24 \\
\hline Дніпропетровська область & 128702 & 111078 & 32257 & 86 & 25 \\
\hline Донецька область & 49114 & 24915 & 10211 & 51 & 21 \\
\hline Житомирська область & 32192 & 27892 & 9679 & 87 & 30 \\
\hline Закарпатська область & 24832 & 21594 & 7033 & 87 & 28 \\
\hline Запорізька область & 84462 & 53079 & 18520 & 63 & 22 \\
\hline Івано-Франківська область & 42114 & 47082 & 12943 & 112 & 31 \\
\hline Київська область & 38173 & 21378 & 8822 & 56 & 23 \\
\hline Кіровоградська область & 27202 & 12058 & 4558 & 44 & 17 \\
\hline Луганська область & 48337 & 13878 & 5765 & 29 & 12 \\
\hline Львівська область & 129688 & 149560 & 31637 & 115 & 24 \\
\hline Миколаївська область & 91244 & 23471 & 8633 & 26 & 9 \\
\hline Одеська область & 114320 & 103111 & 24110 & 90 & 21 \\
\hline Полтавська область & 43053 & 35410 & 13019 & 82 & 30 \\
\hline Рівненська область & 39890 & 30010 & 8246 & 75 & 21 \\
\hline Сумська область & 36781 & 26565 & 9775 & 72 & 27 \\
\hline Тернопільська область & 47662 & 40303 & 12110 & 85 & 25 \\
\hline Харківська область & 173824 & 174996 & 40912 & 101 & 24 \\
\hline Херсонська область & 34452 & 23278 & 9099 & 68 & 26 \\
\hline Хмельницька область & 32152 & 26295 & 9238 & 82 & 29 \\
\hline Черкаська область & 50853 & 36910 & 12002 & 73 & 24 \\
\hline Чернівецька область & 37662 & 30109 & 8100 & 80 & 22 \\
\hline Чернігівська область & 21757 & 19206 & 5982 & 88 & 27 \\
\hline
\end{tabular}

Джерело: побудовано автором на основі [2; 3]. 
Адже заяви абітурієнтів - це потенційна чисельність контингенту студентів першого курсу бакалаврату, звідки маємо наступну ситуацію: загалом, максимальний обсяг місць, передбачених для вступу налічує 17277442 од., тоді як оригіналів подано було лише 1546556 од, що, в результаті, свідчить про незаповненість ліцензійного обсягу ЗВО України на 1324203 чол. або на 76,6 \%. При цьому, спостерігаємо, що кількість заяв у ряді регіонів була значно високою (м. Київ - +131 \% до ліцензійного обсягу, Харківська область - 101\%, Івано-Франківська область - 112 \%, Львівська область - $115 \%)$, аніж їх ліцензійний обсяг.

Рис. 4(a) та рис. 4(б) свідчать, що найбільш критичними в даному контексті, $\epsilon$ Миколаївська (на $91 \%$ ), Луганська (на $88 \%$ ) та Кіровоградська (на $83 \%$ ) області, незаповненість ЗВО яких більше $80 \%$. Проте, якщо Луганський регіон, це один 3 двох регіонів, ЗВО яких тимчасово переміщені до інших міст України із зони антитерористичних операцій, що є логічним, адже фактичне переміщення вплинуло на процес роботи 3ВО, а отже і неспроможність надавати освітні послуги у тій мірі та обсязі що попередньо. Тоді як Миколаївська та Кіровоградська області є кризовими в контексті, спочатку, наповнення ЗВО абітурієнтам, а потім, в результаті, нестачею трудових ресурсів на регіональному ринку, при цьому, не беручи до уваги зовнішню трудову міграцію, яка притаманна регіонам.

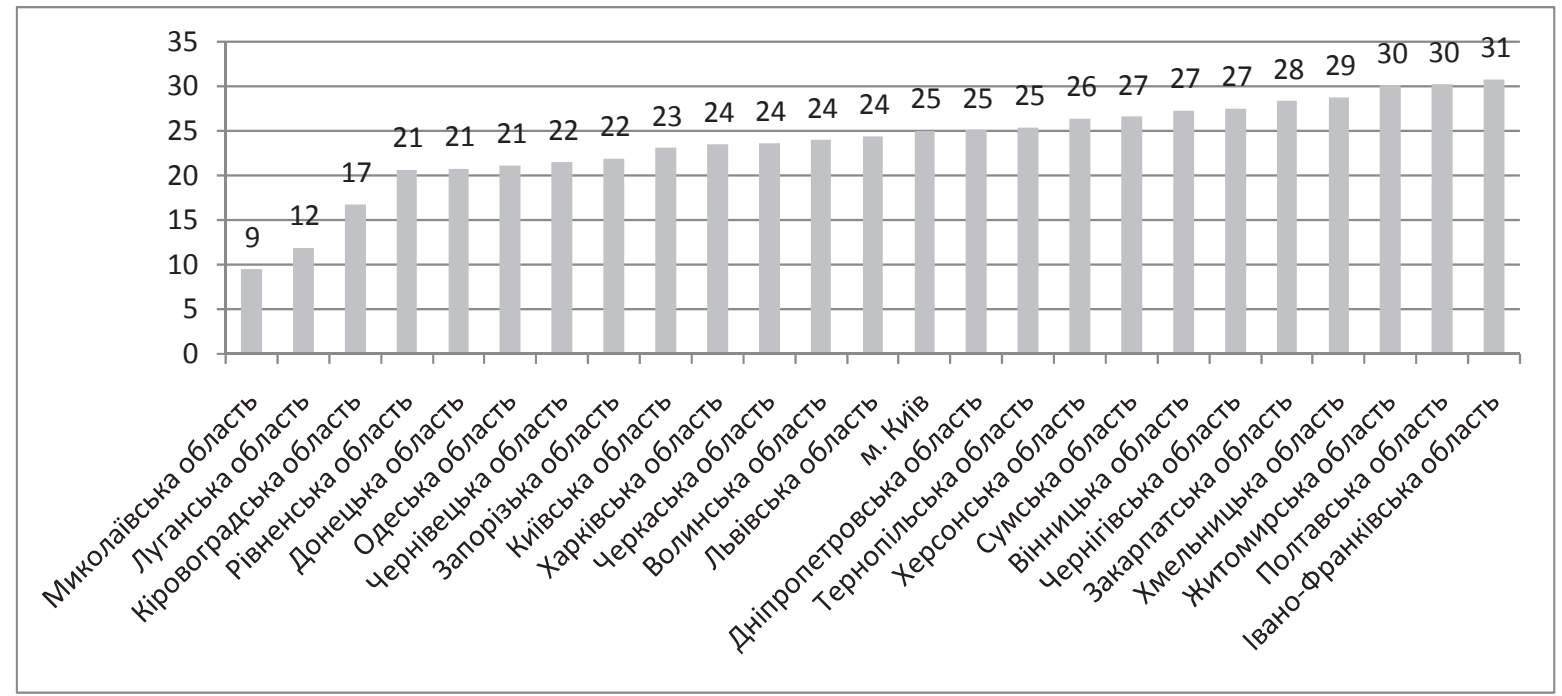

а) відношення заяв до ліцензійного обсягу

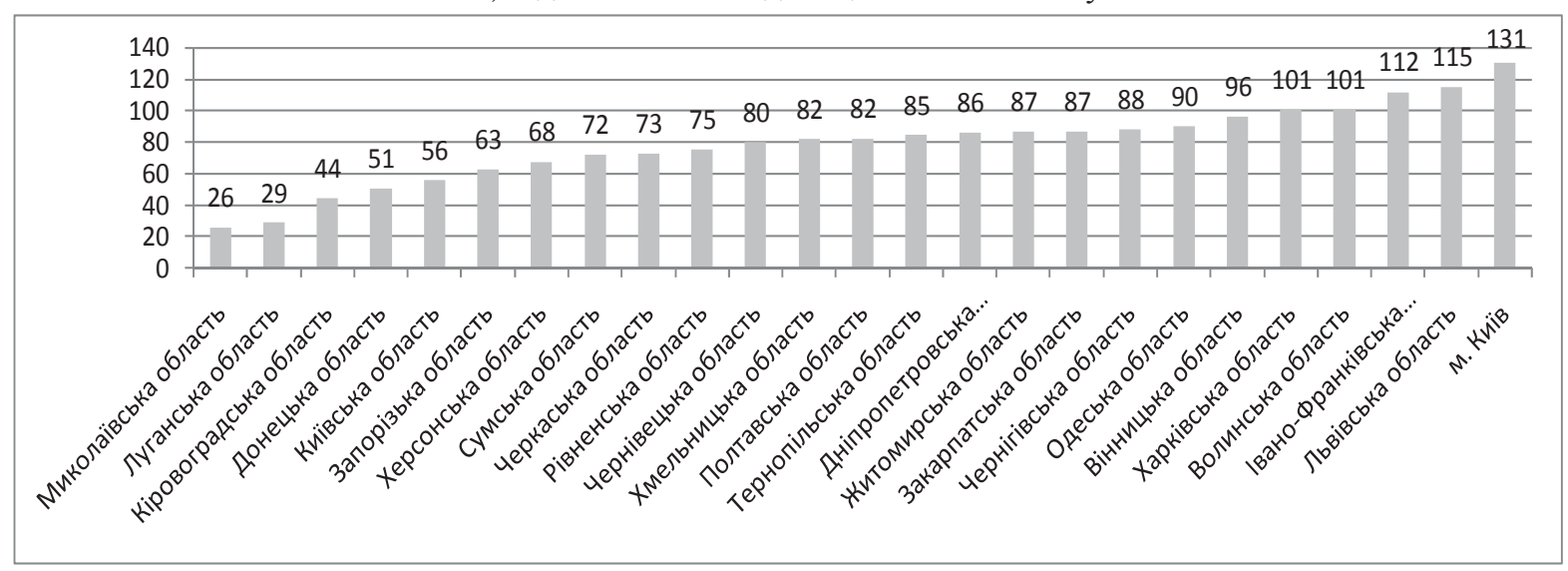

б) відношення оригіналів документів до ліцензійного обсягу

Рисунок 4 - Групування регіонів за рівнем наповненості заявами абітурієнтів ліцензійного обсягу закладів вищої освіти регіону у 2019 році, \%

Джерело: побудовано автором на основі [2; 3$]$. 
Продовжуючи дослідження, акцентуємо увагу на тому, що регіони 3 найвищим ступенем популярності (за кількістю заяв), - це регіони, де середній конкурсний бал абітурієнтів $є$ також, порівняно, найвищим. Далі, табл. 3 репрезентує ТОП-10 найкращий державних 3ВО за результатами вступної кампанії 2018, а також відповідні значення для 2 найбільших 3ВО Кіровоградського регіону з метою компаративістики.

Таблиця 2 - Найкращі державні ЗВО за результатами вступної кампанії 2019

\begin{tabular}{|c|c|c|c|c|}
\hline Місце & 3BO & $\begin{array}{c}\text { Рейтинг } \\
\text { (від } 0 \text { до } \\
100)\end{array}$ & $\begin{array}{c}\text { Загальна } \\
\text { кількість заяв }\end{array}$ & $\begin{array}{c}\text { Середній } \\
\text { конкурсний } \\
\text { бал }\end{array}$ \\
\hline 1 & $\begin{array}{c}\text { Національний університет "Києво-Могилянська } \\
\text { академія" }\end{array}$ & 187,88 & 10,92 & 541 \\
\hline 2 & $\begin{array}{l}\text { Київський національний університет імені Тараса } \\
\text { Шевченка }\end{array}$ & 184,27 & 10,62 & 2699 \\
\hline 3 & $\begin{array}{c}\text { Національний медичний університет імені О.О. } \\
\text { Богомольця } \\
\end{array}$ & 182,58 & 10,69 & 762 \\
\hline 4 & $\begin{array}{c}\text { Національний юридичний університет імені Ярослава } \\
\text { Мудрого }\end{array}$ & 182,09 & 10,63 & 405 \\
\hline 5 & Національний фармацевтичний університет & 182 & 10,52 & 10 \\
\hline 6 & $\begin{array}{c}\text { Львівський національний медичний університет імені } \\
\text { Данила Галицького }\end{array}$ & 181,66 & 10,53 & 438 \\
\hline 7 & \begin{tabular}{|c|} 
Полтавський юридичний інститут Національного \\
юридичного університету імені Ярослава Мудрого
\end{tabular} & 181,46 & 10,91 & 15 \\
\hline 8 & $\begin{array}{c}\text { Вінницький національний медичний університет ім. } \\
\text { М. І. Пирогова }\end{array}$ & 181,45 & 10,6 & 390 \\
\hline 9 & $\begin{array}{c}\text { Київський національний економічний університет } \\
\text { імені Вадима Гетьмана }\end{array}$ & 181,17 & 10,5 & 695 \\
\hline 10 & Київський національний лінгвістичний університет & 181,05 & 10,5 & 250 \\
\hline 131 & $\begin{array}{c}\text { Центральноукраїнський державний педагогічний } \\
\text { університет імені Володимира Винниченка }\end{array}$ & 153,31 & 9,07 & 323 \\
\hline 152 & $\begin{array}{l}\text { Центральноукраїнський національний технічний } \\
\text { університет }\end{array}$ & 149,37 & 8,22 & 139 \\
\hline
\end{tabular}

Джерело: побудовано автором на основі [3].

Як видно з табл. 3, найвищий середній бал аплікаційних заяв, притаманний 3ВО м. Києва (2019 рік: 182,58 - 187,88), (2016 рік: 164,45 - 175,48), Харківська область (166,45 у 2016 році та 182-182,09 - у 2019 році), Львівська область (161,84 - 168,34 у 2016 році та 181,66 у 2019 році). Тоді як для Кіровоградської області - від 133,65 до 155,18 у 2016 році та від 149,37 до 153,31 у 2019 році. При цьому, виходячи із розгорнутого компаративного аналізу, поданого вище, Кіровоградського регіону, маємо зауважити, що, фактично, оригінали подають, а отже вступають до ЗВО з меншими балами, аніж середній конкурсний бал заяв, що ще раз підкреслює демотивацію абітурієнтів вступати до Кіровоградського регіону, причину чого можна пояснити вище представленим аналізом.

Висновки та перспективи подальших досліджень. Таким чином, Кіровоградський регіон, з огляду на результати ЗНО, має значний освітній потенціал, проте не використовує його у повній мірі, адже втрачає, по причині відтоку, найбільш схильних до навчання та генерування нових ідей, абітурієнтів до більш престижних регіонів України, що не лише дестабілізує ситуацію у регіональних 3ВО, а й, в результаті, призводить до зниження потенціалу його людського капіталу, в першу чергу, знижує здатність до інноваційної активності. Усунути дану проблему, можливо, лише шляхом забезпечення відповідного середовища, в першу чергу, заробітної плати та, як результат, підвищення соціально-економічного рівня населення. Останнє 
можливе, на нашу думку, шляхом поглиблення співпраці органів місцевої влади, бізнесу та закладів вищої освіти, з огляду на тенденції світової економіки, саме такий симбіоз дає змогу ефективно розвивати як регіональну, так і національну економіку загалом.

Перспективою подальших пошуків у напрямі дослідження $\epsilon$ розробка диференційованих заходів щодо посилення привабливості навчання у регіональних закладах вищої освіти, покликаних знизити рівень освітньої еміграції в Кіровоградському регіоні.

\section{Список літератури}

1. І Інноваційний вимір розвитку вищої освіти України: сучасні реалії та перспективи: колективна монографія / За заг. ред. д.е.н., проф. О.М. Левченка. Кіровоград: Ексклюзив-Систем, 2015. Ч. І. $580 \mathrm{c.}$

2. Інформаційна система "Конкурс": веб-сайт. URL: http://www.vstup.info/ (дата звернення: 12.10.2019)

3. Інформаційна система "ABIT-POISK": веб-сайт. URL: https://abit-poisk.org.ua/ (дата звернення: 12.10.2019)

4. Інтеграція вищої освіти України в європейський та світовий освітній простір: економічний вимір: монографія / І.С. Каленюк, О.І. Гонта, М.П. Вербовий, Н.І. Холявко; за заг. ред. д.е.н., проф. Каленюк І.С. Чернігів: РВК «Деснянська правда», 2011. 165 с.

5. Каленюк І.С., Куклін О.В. Розвиток вищої освіти та економіка знань : монографія. Київ : Знання, 2012. $343 \mathrm{c}$.

6. Левченко А. О., Царенко І. О., Горпинченко О. В. Особливості формування освітнього потенціалу Кіровоградської області: стан та напрями розвитку. Кіровоградщина - 2025: пріоритети і можливості розвитку : зб. тез доп. наук.-практ. конф., 7 черв. 2017 р. Кропивницький, 2017. С. 45-49.

7. Прокопенко І.Ф., Мельникова О.В. Вища освіта як чинник економічного зростання України: сучасний стан та перспективи розвитку. Економіка : зб. наук. пр. Харківського національного педагогічного університету імені Г.С. Сковороди. 2017. Вип. 17. С. 5-14.

8. Український центр оцінювання якості освіти: веб-сайт. URL: http://testportal.gov.ua/reg/ (дата звернення: 08.10.2019)

9. Ушенко Н.В. Освітні потреби в умовах розбудови економіки знань. Вісник Чернігівського державного технологічного університету. 2013. № 4 (70). С. 22-31.

10. Холявко Н. І. Сектор вищої освіти в системі інноваційного розвитку національної економіки Економіка і управління. 2014. №1. С. 33-37.

11. Царенко, I. О. Проблеми підготовки висококваліфікованих кадрів ЗВО України в умовах формування інноваційної моделі економіки та напрями їх вирішення. Проблеми $і$ перспективи інноваційного розвитку економіки : матеріали $\mathrm{XX}$ ювілейної міжнар. наук.-практ. конф., 7-11 верес. 2015. Одеса, 2015. Т. 1, ч. II. С. 75-81.

12. Tsarenko, I. Educational Component of the Forming of Innovative-Integrated Structures in Ukraine. Центральноукраӥнський науковий вісник. Економічні науки : зб. наук. пр. 2018. Вип. 1 (34). С. 64-74.

\section{References}

1. Levchenko, O.M. (Eds). (2016). Innovatsiinyi vymir rozvytku vyshchoi osvity Ukrainy: suchasni realii ta perspektyvy: kolektyvna monohrafiia [Innovative dimension of the development of higher education in Ukraine: current realities and perspectives: collective monograph]. Kirovohrad: Ekskliuzyv-System [in Ukrainian].

2. Informatsiina systema "Konkurs" [Competition information system]. www.vstup.info. Retrieved from: http://www.vstup.info/ [in Ukrainian].

3. Informatsiina systema "ABIT-POISK" [ABIT-POISK information systemt]. https://abit-poisk.org.ua. Retrieved from: https://abit-poisk.org.ua/ [in Ukrainian].

4. Kaleniuk, I.S., Honta, O.I., Verbovyi, M.P., \& Kholiavko, N.I. (2011). Intehratsiia vyshchoi osvity Ukrainy $v$ yevropeiskyi ta svitovyi osvitnii prostir: ekonomichnyi vymir: monohrafiia [Integration of Higher Education of Ukraine into European and World Educational Space: Economic Dimension: Monograph]. I.S. Kaleniuk (Ed.). Chernihiv: RVC "Desnianskaya Pravda" [in Ukrainian].

5. Kaleniuk, I.S. \& Kuklin, O.V. (2012). Rozvytok vyshchoi osvity ta ekonomika znan : monohrafiia [Higher education development and knowledge economy: monograph]. I.S. Kaleniuk. (Ed.) K.: Znannia. 
(Suchasna nauka) [in Ukrainian].

6. Levchenko, A.O., Tsarenko, I.O., \& Horpynchenko, O.V. (2017). Osoblyvosti formuvannia osvitnoho potentsialu Kirovohradskoi oblasti: stan ta napriamy rozvytku [Features of formation of educational potential of Kirovograd region: state and directions of development]. Kirovohrad region - 2025: priorities and opportunities for development: Naukovo-praktychna konferentsiya (7 chervnia 2017) - International Scientific and Practical Conference (pp. 45-49). KNTU: Kirovohrad: KOD [in Ukrainian].

7. Prokopenko, I.F., \& Melnykova, O.V. (2017). Vyshcha osvita yak chynnyk ekonomichnoho zrostannia Ukrainy: suchasnyi stan ta perspektyvy rozvytku [Higher education as a factor of economic growth of Ukraine: current state and prospects for development]. Ekonomika - Economy, 17, 5-14 [in Ukrainian].

8. Ukrainskyi tsentr otsiniuvannia yakosti osvity [Ukrainian Center for Educational Quality Assessment]. testportal.gov.ua. Retrieved from: http://testportal.gov.ua/reg/ [in Ukrainian].

9. Ushenko, N.V. (2013). Osvitni potreby v umovakh rozbudovy ekonomiky znan [Educational Needs in Developing Knowledge Economy]. Visnyk Chernihivskoho derzhavnoho tekhnolohichnoho universytetu Bulletin of the Chernihiv State Technological University, 4 (70), 22-31 [in Ukrainian].

10. Kholiavko, N.I. (2014). Sektor vyshchoi osvity v systemi innovatsiinoho rozvytku natsionalnoi ekonomiky [The Higher Education Sector in the System of Innovative Development of the National Economy]. Ekonomika i upravlinnia - Economy and management, 1, 33-37 [in Ukrainian].

11. Tsarenko, I.O. (2015). Problems of preparation of highly qualified personnel of ZVO of Ukraine in the conditions of formation of innovative model of economy and directions of their solution [Problemy pidhotovky vysokokvalifikovanykh kadriv ZVO Ukrainy $v$ umovakh formuvannia innovatsiinoi modeli ekonomiky ta napriamy yikh vyrishennia]. Kirovohrad region - 2025: priorities and opportunities for development: Naukovo-praktychna konferentsiya (7-11 veresnia 2015) - XX Anniversary International Scientific and Practical Conference (pp. 75-81). Odessa [in Ukrainian].

12. Tsarenko, I. (2018). Educational Component of the Forming of Innovative-Integrated Structures in Ukraine. Naukovi pratsi Kirovohrads'koho natsional'noho tekhnichnoho universytetu. Ekonomichni nauky - The collection of Scientific works of Kirovohrad National Technical University. Economic sciences, 34, 64-74 [in English].

Ilona Tsarenko, Senior Lecturer, $\mathrm{PhD}$ in Economics (Candidate of Economic Sciences)

Central Ukrainian National Technical University, Kropyvnytskyi, Ukraine

\section{Prerequisites of the Forming of the Innovative Integrated Structures in the Context of the Increased Educational Migration: Regional Aspect}

The paper is devoted to the prerequisites for the forming of the innovative integrated structures in the context of increased educational migration. The results of external independent evaluation by the all schoolling subject in the Kirovohrad region have been evaluated.

The particular attention is paid to the Kirovohrad region within the framework of the paper, as an example it is showed the relationship between the level of educational migration and, in the future, the decreasing in the level of attractiveness of the region and the level of socio-economic development. The analysis found that no high-performing students entered the regional universities, indicating that the universities of the region were not priority among such entrants, although, according to the results of the external independent assessment of graduates of schools of the Kirovohrad region, about 632 persons in 2019 passed tests for 180-200 points. A comparative analysis of the effectiveness of the introductory campaign of the higher education institutions by the territorial section was carried out, the results of which revealed territorial asymmetries in the occupancy of higher education institutions, namely, we observe that the most critical situations in this context are the Mykolaiv (by 91\%), Luhansk (by 88\%) and Kirovohrad (by 83\%) regions, the unfilled area of which is more than $80 \%$.

The qualitative analysis of the applications in the regional HEIs and TOP-10 universities with the highest rating score of external independent assessment has been carried out. It was found that deepening the cooperation of local authorities, businesses and higher education institutions, that is, creating the preconditions for the forming of innovative integrated structures, is the most effective tool for the eliminating the manifestations of educational migration.

The prospect of further research direction is the development of differentiated measures to enhance the attractiveness of education in regional higher education institutions aimed at reducing the level of educational emigration in the Kirovohrad region.

higher education institutions, higher education, external independent assessment, innovative-integrated structures 